7. Цивільний кодекс України: Закон України від 16 січня 2003 р. № 435-IV. Biдомості Верховної Ради України. 2003. №№ 40-44. Ст. 356. (Із змінами).

8. Про товариства з обмеженою та додатковою відповідальністю: Закон України від 6 лютого 2018 р. № 2275-VIII. Відомості Верховної Ради Украӥни. 2018. № 13. Ст. 69. (Із змінами).

9. Рішення господарського суду Запорізької області від 23 січня 2012 р. у справі № 8/188/10. Єдиний державний реєстр судових рімень. URL: http://www.reyestr.court.gov.ua/Review/ 21398800

10. Рішення господарського суду Дніпропетровської області від 12 серпня 2010 р. у справі № K7/87-10. Єдиний державний реєстр судових рішень. URL: http://www.reyestr.court.gov.ua/ Review/10837039

11. Корпоративне право: навчальний посібник / О.В.Гарагонич, С. М. Грудницька, Л. М. Дорошенко та ін.; за заг. ред. О. В. Гарагонича, С. М. Грудницької, Л. М. Дорошенко. Київ: Видавничий дім «АртЕк», 2018. 400 с.

DOI 10.31558/2518-7953.2019.1.7

УДК 346.7

С. М. Павлюк

аспірант Донецького національного університету імені Василя Стуса

\title{
ЩОДО ДОГОВІРНОГО РЕГУЛЮВАННЯ ПЕРЕВЕЗЕННЯ ВАНТАЖІВ У ПРЯМОМУ ЗМІШАНОМУ СПОЛУЧЕННІ
}

Ключові слова: договір перевезення, пряме змішане сполучення, перевезення вантажів, транспортне законодавство, транспорт, перевізник, організаційний договір, вузлова угода.

Сучасний етап розвитку економіки вимагає нових оптимальних способів організації перевізного процесу за допомогою правових засобів, в якості яких виступають транспортні договори. В умовах пошуку нових логістичних підходів до доставки вантажів, забезпечення оптимальної взаємодії різних видів транспорту при здійсненні перевезень вантажів дослідження договірних відносин між учасниками перевезення вантажів у прямому змішаному сполученні стають все більш актуальними.

Як зазначається в Національній транспортній стратегії України на період до 2030 року, схваленій розпорядженням Кабінету Міністрів України від 30 травня 2018 р., транспортна система України має низький рівень розвитку інтермодальних, мультимодальних перевезень, що знижує ï конкурентоспроможність та обмежує вихід української продукції на світовий транспортний ринок. Мультимодальні та інтермодальні перевезення вантажів займають в Україні не більше 0,5 \% транспортного ринку, за цим показником Україна відстає від держав-членів СС та інших розвинутих держав світу у 20-30 разів [1]. 
Правові питання перевезення вантажів у прямому змішаному сполученні вже ставали предметом дослідження в науковій юридичній літературі в різні часи. Зокрема, питанням правового регулювання перевезення вантажів у прямому змішаному сполученні приділили свою увагу такі вчені, як Т. О. Колянковська, В. В. Кадала, В. А. Попов, С. Ю. Морозов, О. В. Карпєєв, В. В. Вітрянський, Н. О. Бутакова, В. А. Єгіазаров, Г. Б. Астановський, В. Т. Смірнов, Н. М. Тютріна, В. В. Тюп та інші. Проте у сучасних умовах розвитку транспортної системи України, впровадження нових принципів формування та координації державної політики в транспортній галузі зазначені питання набувають особливого значення та потребують переосмислення.

У зв'язку з иим, метою иієї статті є виявлення особливостей договірного регулювання перевезення вантажів у прямому змішаному сполученні та визначення напрямів вдосконалення відповідного законодавства.

Загальні положення щодо перевезення у прямому змішаному сполученні містяться у статті 913 Цивільного кодексу України, а норми щодо договору перевезення вантажу в прямому змішаному сполученні передбачено у статті 312 Господарського кодексу України (далі - ГК України), відповідно до частини 1 якої за договором перевезення вантажу в прямому змішаному сполученні перевезення здійснюється від вантажовідправника до вантажоодержувача двома або більше перевізниками різних видів транспорту за єдиним перевізним документом [2]. Відповідно до частини 2 зазначеної статті загальні правила, передбачені статтею 307 ГК України, застосовуються до договору перевезення вантажу в прямому змішаному сполученні з урахуванням особливостей, що передбачені транспортними кодексами чи статутами. Аналіз статей 312 та 307 ГК України дає підстави зробити висновок, що при перевезенні вантажів у прямому змішаному сполученні, як і при перевезенні вантажів одним видом транспорту, можуть укладатися: довгостроковий договір (у разі необхідності здійснення систематичних перевезень вантажів), за яким перевізник зобов'язується у встановлені строки приймати, а вантажовідправник - подавати до перевезення вантажі у погодженому сторонами обсязі; разовий договір перевезення конкретної партії вантажу, укладення якого підтверджується складенням перевізного документа; вузлові угоди, порядок укладення яких встановлюється транспортними кодексами та статутами. Згідно зі ст. 39 Закону України «Про транспорт» [3] відносини підприємств різних видів транспорту під час перевезень пасажирів, вантажів, багажу, пошти визначаються кодексами (статутами) окремих видів транспорту, а також укладеними на їх основі договорами (вузловими угодами). Розроблення та укладення вузлових угод здійснюється в порядку, який встановлюється Кабінетом Міністрів України.

В цілому, змішані перевезення дають вантажовласникові ряд переваг. Зокрема, вантажовласник звільняється від необхідності укладати договори, вступати у юридичні відносини з різними перевізниками. 
Проблема встановлення особливостей укладення господарських договорів, що опосередковують перевезення вантажу в прямому змішаному сполученні, обумовлена відсутністю окремого закону, який би встановлював такі норми, зокрема закону про змішані (комбіновані) перевезення. В чинних транспортних статутах та правилах перевезень також зазначені норми не систематизовані. На це неодноразово зверталася увага в науковій юридичній літературі $[4,5,6]$.

Сутність зобов'язань, що витікають з вузлових угод, зводиться до організації роботи транспортних організацій різних видів транспорту з подачі транспортних засобів під навантаження (якщо вантаж доставлений в пункт перевалки контрагентом) або вивантаження, прийняття вантажів, їх перевалки на інший вид транспорту для доставки одержувачу, вказаному в транспортній накладній на перевезення вантажу в прямому змішаному сполученні. Окремі питання порядку організації та здійснення таких перевезень врегульовано транспортними статутами та кодексами, а також Правилами перевезень вантажів у прямому змішаному залізничноводному сполученні. Вказані Правила поширюють свою дію тільки на залізничноводне сполучення [6, с. 135-136].

Слід також враховувати дигіталізацію перевізного процесу та пов'язане 3 цим прийняття відповідного законодавства, зокрема, законів України «Про електронні документи та електронний документообіг», «Про електронні довірчі послуги», «Про електронну комерцію» та відповідних підзаконних нормативно-правових актів. Як справедливо зазначає Е. М. Деркач, встановлення правил використання електронних документів у господарській діяльності у сфері транспорту здійснюється на рівні індивідуального регулювання (за допомогою угод про використання електронної форми договору). Проте правовий порядок потребує окреслення меж індивідуально-правового регулювання, у зв'язку з чим доцільним є законодавче закріплення можливості та особливостей складання електронної транспортної накладної, яка підтверджує укладення договору перевезення вантажу транспортом [7, с. 316].

Крім цього, при організації транспортного процесу необхідно враховувати глобалізацію економіки і появу транснаціональних корпорацій. На транспорті складається зовсім новий вид підприємництва - глобальне логістичне провайдерство, яке вимагає відповідної організації транспортного процесу і зниження транспортних витрат [8, с. 130]. Отже, інноваційна економіка вимагає нових логістичних підходів до доставки вантажів. Рішення такого завдання безпосередньо пов'язане із забезпеченням оптимальної взаємодії різних видів транспорту при здійсненні перевезень вантажів. С. Ю. Морозов, досліджуючи оптимальні способи організації перевізного процесу за допомогою правових засобів, зазначає, що в якості таких виступають транспортні організаційні договори [8, с. 129]. Так, договір перевезення вантажів у прямому змішаному сполученні нерозривно по- 
в'язаний з організаційними договорами між транспортними організаціями (вузловими угодами, договорами на централізоване завезення (вивезення) вантажів тощо). Їх взаємозалежність така, що без існування організаційного договору неможливо укласти або виконати договір перевезення вантажу в прямому змішаному сполученні, без якого, в свою чергу, немає сенсу в організаційному транспортному договорі. Зазначений автор вважає вузлову угоду і угоду про організацію прямих змішаних перевезень організаційними, оскільки спрямовані вони на організацію правовідносин за договором перевезення вантажів у прямому змішаному сполученні $[8$, с. 136].

Вітчизняні вчені, досліджуючи договірні відносини, що опосередковують перевезення вантажів у прямому змішаному сполученні, також пропонують доктринальні визначення договорів такого виду. Так, як зазначає В. В. Кадала, договір перевезення вантажів у прямому змішаному сполученні - це договір, укладений оператором змішаного перевезення або перевізником з вантажовласником на доставку вантажу двома та більше видами транспорту. Він є господарським договором, самостійним видом договору, що застосовується у сфері перевезення вантажів, його не можна поєднувати 3 договорами підряду, майнового найму, схову. Такий договір визначається як угода, за якою перевезення здійснюється від вантажовідправника до вантажоодержувача двома або більше перевізниками різних видів транспорту за єдиним перевізним документом [6, с. 186-187].

Існує певна специфіка у договорі перевезення вантажів у прямому змішаному сполученні, що укладається відправником вантажу з перевізником, яким є перша транспортна організація, що приймає вантаж до перевезення. Такий договір вирізняється особливим змістом, наприклад, щодо умов договору: про строк доставки вантажу, що збільшується на час, необхідний для перевалювання перевезеного вантажу з одного виду транспорту на інший; про забезпечення збереження вантажу з урахуванням того, що цей обов'язок розподіляється між усіма транспортними організаціями, які беруть участь у процесі перевезення; про сплату провізної плати та всіх належних транспортним організаціям платежів. Особливо ретельно регламентується відповідальність транспортних організацій, що беруть участь у транспортуванні вантажу. Збільшується й сфера відповідальності відправника вантажу, зокрема за рахунок додаткової відповідальності за порушення вимог законодавства щодо оформлення транспортних документів і навантаження вантажів у транспортні засоби, що спричинили негативні наслідки у зв'язку з перевезенням вантажів у прямому змішаному сполученні (наприклад, наднормативний простій транспортних засобів у пункті перевалки вантажів з одного виду транспорту на інший) [6, с. 80].

Поряд із договорами, що безпосередньо стосуються процесу переміщення (доставки) вантажів, значне місце належить також договорам, що мають іншу 
мету, а саме: регламентувати організацію роботи з подавання транспортних засобів та пред'явлення вантажів до перевезення, їх перевалювання з одного виду транспорту на інший тощо. До таких організаційних договорів належать і вузлові угоди, що укладаються між транспортними організаціями різних видів транспорту [6, с. 184-185].

При цьому, як зазначає В. В. Кадала, вузлова угода виступає у вигляді не єдиного документа, а як сукупність нормативних документів (ЄТП, Договір, Правила користування вагонами та контейнерами та ін.), які доповнюють один одного. У зв’ язку з відсутністю законодавчого визначення терміну «вузлова угода» пропонується під цим терміном розуміти сукупність договорів, які носять організаційний характер і визначають взаємні відносини транспортних організацій, які беруть участь у прямому змішаному сполученні, згідно з якими вони зобов’ язуються за плату переміщувати вантажі з одного виду транспорту на інший з метою продовження процесу доставки [6, с. 184-185].

В цілому погоджуючись з пропозицією зазначеного автора про закріплення поняття, порядку укладення та змісту вузлових угод в чинному законодавстві, що регламентує змішані перевезення, слід зауважити, що перевізник укладає договір перевезення не 3 вантажовласником, а $з$ вантажовідправником, тобто не завжди вантажовласник є відправником вантажу. Проте право на подання претензій чи позовів відповідно до чинного законодавства за загальним правилом належить саме відправнику вантажу, а не його власнику. Крім цього, правий статус оператора змішаного перевезення, на жаль, в чинному законодавстві не регламентований, хоча необхідність цього є безумовною. Так, термін «оператор змішаного перевезення» визначено в законодавстві лише стосовно повітряних перевезень вантажів у Правилах повітряних перевезень вантажів, затверджених наказом Державної служби по нагляду за забезпеченням безпеки авіації від 14.03.2006 p. Оператором змішаного перевезення є особа, яка від власного імені або через іншу особу, що має повноваження від такої особи, укладає договір змішаного перевезення як сторона договору, бере на себе зобов'язання на виконання договору i яка не є агентом вантажовідправника чи перевізника, що беруть участь в операціях щодо змішаного перевезення. Доцільною вбачається регламентація в законодавстві правового статусу оператора змішаного перевезення для всіх видів транспорту, розмежування оператора змішаного перевезення з іншими учасниками, які можуть брати участь у перевезенні, наприклад, транспортного агента, транспортного експедитора тощо.

В. А. Попов, також досліджуючи правовідносини у сфері перевезення вантажів у прямому і прямому змішаному сполученні, пропонує поділяти договори перевезення вантажів на основні й допоміжні. При цьому основними договорами автор пропонує вважати такі, що безпосередньо забезпечують переміщення ван- 
тажів, в тому числі договори перевезення останніх окремими видами транспорту, договір чартеру (фрахтування) тощо. Допоміжні ж спрямовані на забезпечення технологічного процесу транспортування вантажів. Їх допоміжний характер по відношенню до основних договорів полягає не в їх додатковому характері, оскільки ці договори є самостійними договірними конструкціями, а в тому, що виникнення й реалізація відповідних правовідносин покликані забезпечити технологічний процес навантаження, транспортування, перевалки, розвантаження й видачі вантажу. До вказаних конструкцій належать договори на експлуатацію залізничної колії, договір на подачу й забирання вагонів, на управління аеродромом, договір про аеропортне обслуговування та ін. [9, с. 176].

Т. А. Колянковська до системи договорів, що опосередковують взаємовідносини учасників перевезень вантажів в прямому змішаному сполученні, відносить: а) довгостроковий договір або договір про надання транспортних засобів та пред’явлення вантажів до перевезення; б) реальний договір перевезення вантажу в прямому змішаному сполученні; в) вузлові угоди, що укладаються між транспортними організаціями різних видів транспорту [5, с. 5].

Дійсно, транспортний процес при перевезеннях вантажів складається 3 трьох основних стадій: 1) пред'явлення вантажу і надання транспортних засобів під навантаження; 2) перевезення вантажу; 3) видачі вантажу. Ця система характеризується єдністю та послідовністю, яка передбачає з’єднання цих елементів транспортного процесу у внутрішню організовану структуру. Транспортні операції і роботи, відокремлені від цієї єдиної системи, не в змозі забезпечити доставку вантажу. Лише в єдності з іншими стадіями перевізного процесу досягається його кінцева мета - доставка в пункт призначення.

Відносини, що виникають при перевезенні вантажів у прямому змішаному сполученні наразі відповідно до чинного законодавства опосередковуються договором перевезення вантажу у прямому змішаному сполученні (традиційний реальний договір перевезення конкретного вантажу з деякими особливостями його змісту) і угодами, що укладаються між транспортними організаціями різних видів транспорту, які регламентують порядок їх роботи з організації таких перевезень вантажів [6, с. 87].

До правових ознак договору перевезення вантажу у прямому змішаному сполученні у літературі відносять такі: це господарський договір, сторонами якого $\epsilon$ вантажовідправник та перевізник; договір визначає майново-господарські зобов’язання, що виникають при здійсненні одного з видів господарської діяльності перевезення вантажів; оплатність договору, тобто цей вид транспортної послуги надається за плату за перевезення вантажів; за способом укладення вказаний договір є реальним, тому що момент його укладення збігається з моментом прийняття вантажу до перевезення; це строковий господарський договір, оскільки по- 
в'язаний з виконанням зобов'язань його сторін у встановлений законодавством чи договором строк [6, с. 87].

Правова природа вузлових угод в юридичній літературі визначається неоднозначно. Вона обумовлена правовідносинами, що виникають 3 договору прямого змішаного перевезення вантажів, що здійснюється за участю перевізників різними видами транспорту. Множинність осіб на стороні виконавця зобов'язання з перевезення зумовила проблему правової кваліфікації відповідних договірних відносин [8, с. 358$]$.

В науковій літературі було обгрунтовано пропозиції щодо застосування концепції «єдиного перевізника» до перевізників різних видів транспорту, які беруть участь у змішаному перевезенні вантажів. Деякі дослідники вважають, що до договору перевезення вантажів у прямому змішаному сполученні концепція «єдиного перевізника» непридатна, тут мова йде про виконання обов’язку по доставці вантажу першим перевізником, який уклав договір, та залучає до виконання свого обов'язку третіх осіб [8, с. 361]. В. В. Вітрянський справедливо зазначає, що транспортні організації є юридичними особами, які самостійно вступають в договірні відносини, і ні за яких умов не можуть утворювати якийсь фантом «єдиного перевізника»... Учасники зазначених угод діють від свого імені і не набувають ніяких прав і обов'язків щодо вантажовідправників і вантажоодержувачів. Вузлові угоди пов'язані тільки з організацією виконання обов'язків перевізника 3 доставки вантажу в пункт призначення, причому тільки в частині передачі вантажу з одного виду транспорту на інший [10, с. 26].

Як справедливо зазначає С. Ю. Морозов, вузлові угоди вже не в повній мірі здатні задовольнити потреби учасників перевезень вантажів в прямому змішаному сполученні. У зв’язку з цим, поряд з вузловою угодою автор пропонує застосовувати договір про організацію прямих змішаних перевезень вантажів, під яким розуміється дво- або багатосторонній договір між оператором змішаного перевезення і транспортною організацією або транспортними організаціями, що регламентує порядок організації та здійснення обов’ язків перевізника (перевізників) 3 доставки вантажу в прямому змішаному сполученні. Охоплюючи всі стадії перевізного процесу, цей договір здатний замінити не тільки вузлову угоду, але і договори на централізоване ввезення (вивезення) вантажів. При цьому договір про організацію перевезень вантажів в прямому змішаному сполученні в цій частині буде рамковим організаційним договором, який регулює взаємовідносини з організації виконання разових (локальних) договорів (договору перевезення вантажів і договору про пред'явлення вантажу до перевезення). При цьому вузлову угоду автор визначає як цивільно-правовий договір, відповідно до якого перевізники різних видів транспорту зобов'язуються здійснювати в установленому договором порядку у відношенні один до одного узгоджені дії в інтересах вантажовідправ- 
ника (вантажоодержувача), спрямовані на своєчасну передачу вантажу в пунктах перевалки $з$ одного виду транспорту на інший з метою організації виконання обов'язків перевізника з доставки вантажу в прямому змішаному сполученні. При цьому, участь у договорах про організацію прямих змішаних перевезень вантажів в якості сторони оператора змішаного перевезення вантажів, на думку С. Ю. Морозова, не перетворює такий договір у договір транспортної експедиції, так само як укладення експедитором договору з перевізником не перетворює договір перевезення у транспортно-експедиторський договір. 3 одного боку, оператор вступає у відносини з вантажовідправником, укладаючи з ним договір транспортного експедирування, який передбачає обов'язок організувати перевезення вантажів. 3 іншого боку, виконання цього обов'язку передбачає укладання оператором договорів з перевізниками, які беруть участь у перевезенні вантажу в прямому змішаному сполученні [8, с. 378].

Підсумовуючи викладене, можна зробити наступні висновки.

У зв'язку з незадовільною правовою регламентацією перевезень вантажів у прямому змішаному сполученні у вітчизняному законодавстві регулювання відповідних відносин здійснюється переважно на індивідуальному (договірному) рівні иляхом укладення господарських договорів. До правових ознак договору перевезення вантажу у прямому змішаному сполученні належать такі: иуе господарський договір, сторонами якого є вантажовідправник та перевізник (при зміманих перевезеннях вантажів характерною є наявність множинності осіб на стороні виконавця); договір опосередковує зобов'язання, щзо виникають при здійсненні одного з видів господарської діяльності- перевезення вантажів; оплатність договору; за способом укладення вказаний договір є реальним та строковим господарським договором.

Дослідження проблемних питань договірного регулювання перевезення вантажів у прямому змішаному сполученні вказуе на доиільність закріплення загальних положень щзодо транспортних організаційних договорів різними видами транспорту в ГК Україні, розиирення видів таких договорів новими договірними конструкціями, зокрема договором про організацію прямих змішаних перевезень, закріплення на рівні на рівні окремого закону про змімані перевезення особливостей укладення договорів, щуо опосередковують перевезення вантажів у прямому змішаному сполученні, в електронній формі, зокрема єдиного електронного перевізного документу, щзо підтверджує укладення зазначених договорів. Дочільною вбачається регламентація правового статусу оператора змішаного перевезення для всіх видів транспорту, розмежування його з іншими учасниками, які можуть брати участь у перевезенні, зокрема, транспортного агента, транспортного експедитора тощу. Оператором змішаного перевезення слід вважати особу, яка від власного імені або через іншу особу, щз має повноваження 
від такої особи, укладає договір змішаного перевезення як сторона договору, бере на себе зобов'язання на виконання договору і яка не є агентом вантажовідправника чи перевізника, що беруть участь в операціях щодо змішаного перевезення.

Розглянуті проблеми договірного регулювання перевезення вантажів у прямому змішаному сполученні не $\epsilon$ вичерпними, а запропоновані варіанти їх вирішення залишаються відкритими для наукової дискусії та можуть бути основою для подальших наукових досліджень.

1. Про схвалення Національної транспортної стратегії України на період до 2030 року: Розпорядження Кабінету Міністрів України від 30 травня 2018 р. Офіційний вісник України. 2018. № 52. Ст. 1848.

2. Господарський кодекс України: Закон України від 16 січня 2003 р. № 436-IV. Відомості Верховної Ради України. 2003. № 18, № 19-20, № 21-22. Ст. 144. (Із змінами).

3. Про транспорт: Закон України від 10 листопада 1994 р. № 232/94-ВР. Відомості Верховної Ради Украӥни. 1994. № 51. Ст. 446. (Із змінами).

4. Деркач Е. М., Павлюк С. М. Актуальні питання правового регулювання перевезення вантажів у прямому змішаному сполученні. Підприємництвво, господарство і право. 2017. № 12. C. 89-93.

5. Колянковська Т. О. Правове регулювання перевезень вантажів в прямому змішаному сполученні: автореф. дис. ... канд. юрид. наук: спец. 12.00 .03 «Цивільне право і цивільний процес; сімейне право; міжнародне приватне право». Одеса, 2007. 19 с.

6. Кадала В. В. Правове регулювання перевезень вантажів у прямому змішаному сполученні: дис. ... канд. юрид. наук: спец. 12.00.04 «Господарське право; господарсько-процесуальне право». Київ, 2011. 232 с.

7. Деркач Е. М. Електронна накладна при здійсненні перевезення вантажів залізничним транспортом: правові засади застосування. Форум права. 2012. № 4. С. 314-321.

8. Морозов С. Ю. Система транспортных организационных договоров: дис... д-ра юрид. наук: спец. 12.00.03 «Гражданское право; предпринимательское право; семейное право; международное частное право». М., 2011. 451 с.

9. Попов В. А. Правовідносини у сфері перевезення вантажів у прямому та прямому змішаному сполученні: дис. ... канд. юрид. наук: спец. 12.00 .03 «Цивільне право і цивільний процес; сімейне право; міжнародне приватне право». Харків, 2017. 201 с.

10. Витрянский В. В. Договоры, регулирующие перевозки грузов в прямом смешанном сообщении. Хозяйство и право. 2001. № 6. С. 25-29. 